\title{
STUDY THE EXPRESSION OF TETRASPANIN (CD81) ON B CELLS IN RESPONSE TO INTERFERON THERAPY IN CHRONIC HCV PATIENTS
}

\author{
Ebtehag Helmy Hassan ${ }^{1}$,Naglaa Ali Khalifa ${ }^{1}$, Sahar Gouda Zaghlol, , Ahmed Sallam Soliman ${ }^{1}$ \\ ${ }^{1}$, clinical and chemical pathology department, ${ }^{2}$ internal medicine department, Faculty of Medicine,
} Zagazig University, Egypt

\begin{abstract}
Hepatitis $\mathrm{C}$ virus (HCV) infection causes life threatening disease due to its persistence in the liver, over time leading to cirrhosis and hepatocellular carcinoma. Therapeutic intervention with interferon (INF) - alpha combined with ribavirin is aimed at viral clearance, Interferon and ribavirin might discontinue the virus induced hepatocytes damage, thus slowing down the progress to end- stage liver disease. It has been demonstrated that HCV virion, via major structure envelop (E) protein 2 or EIE2 complex could specifically bind to human CD81 molecule, thereby altering the cellular activities in B cells, T cells and natural killer (NK) cells. CD81, a surface protein belonging to the tetraspanin family, facilitates B-T cell interaction in the process of antigen presentation Evidence has revealed that CD81 on B and T cells substantially enhanced T helper IL-4 secretion and NK-cell CD81 enabled E2-mediated reduction of the IFN-gamma levels Those data suggest that CD81 might activate the pathway leading to a predominant type- 2 immune response, and as such be prone to cause a strong antibody production but weak or insufficient cytotoxic activities to clear the. The aim of this work was to investigate the clinical relevance and the possible mechanism of CD81 down-regulation under IFNalpha treatment to detect possible role of CD 81 in response to INF therapy of chronic HCV patients.

Subjects and Methods: The study included: Group I: 10 healthy subjects. And $60 \mathrm{HCV}$ patients classified into 3 groups: Group II: 20 chronic HCV patients have not received treatment Group IIIa: 20 chronic HCV patients have received treatment responsive to treatment Group IIIb: 20 chronic HCV patients have received treatment not responsive to treatment the patients were subjected to: $(\mathrm{CBC})$.liver and kidney function tests and special investigation CD 81, CD19, CD 22.

Results: TLC and PLT higher in group I while ALT and AST were significantly higher in group II, while T. bilirubin was significantly higher in group IIIb, Direct bilirubin was significantly higher in group II ,and Alb was significantly higher in group I ,ASMA and ANA more higher in group IIIb, AFP and TSH were significantly higher in group IIIb , there was negative correlation between CD81 and TLC positive correlation between ALT, AST and CD81 were positively correlated to $\mathrm{T}$ Bilirubin, $\mathrm{D}$ Bilirubin and CD81.There was also significant negative correlation between Albumin and CD81. CD81, CD19, CD22 and Lymphocytes were significantly higher in group IIIb.

Conclusion: In conclusion, CD81 down-regulation is a primary host response to interferon-alpha-based therapy and an immunophenotype associated with anti-HCV sustained virological response (SVR)

Key words:HCV,CD81, interferone

Corresponding author:Ahmed Sallam Soliman ,01275666827, nancyabdelhamid@yahoo.com
\end{abstract}

\section{INTRODUCTION}

H epatitis $\mathrm{C}$ virus (HCV) infection causes life threatening disease due to its persistence in the liver, over time leading to cirrhosis and hepatocellular carcinoma. Therapeutic intervention with interferon (INF) - alpha combined with ribavirin is aimed at viral clearance ${ }^{(1)}$

Interferon and ribavirin might discontinue the virus induced hepatocytes damage, thus slowing down the progress to end- stage liver disease ${ }^{(2)}$.The combination they could exert apparent eradication of HCV viraemia in $46-78 \%$ of the treated patients ${ }^{(3)}$.

There are many virological (viral genotype and initial viral load) and host factors (HCV specific T-cell function to elicit interahepatic cytotoxicity) affecting therapeutic efficiency ${ }^{(1)}$. T cell produces type- 1 cytokines, such as INF- gamma, and to suppress type- 2 cytokines such as interleukin
(IL-4 and IL-10) and most likely favor a successful response to treatment ${ }^{(4)}$. Also genetic polymorphism affect function or exdpression of cytokines may be associated with therapeutic response against chronic HCV infection ${ }^{(5)}$.

It has been demonstrated that $\mathrm{HCV}$ virion, via major structure envelop $(\mathrm{E})$ protein 2 could specifically bind to human CD81 molecule, thereby altering the cellular activities in $\mathrm{B}$ cells, $\mathrm{T}$ cells and natural killer $(\mathrm{NK})$ cells ${ }^{(6)}$. CD81, a surface protein belonging to the tetraspanin family, facilitates B-T cell interaction in the process of antigen presentation ${ }^{(7)}$.Evidence has revealed that CD81 on B and T cells substantially enhanced $\mathrm{T}$ helper IL-4 secretion and NK-cell CD81 enabled E2-mediated reduction of the IFNgamma levels ${ }^{(7)}$. Those data suggest that CD81 might activate the pathway leading to a predominant type- 2 immune response, and as 
such be prone to cause a strong antibody production but weak or insufficient cytotoxic activities to clear the virus ${ }^{(8)}$. Downregulation of CD81 has been demonstrated in association with a decrease in the HCV viral load in IFN-alpha recipients. This gives rise to the possibility for evaluating the CD81 status in correlation with the HCV pathogenesis and therapeutic responsiveness (9).

\section{PATIENTS AND METHODS}

This study was conducted in Clinical and Chemical pathology department and internal medicine, Zagazig University Hospitals during the period May 2012 to September 2014 ,all participants were informed adequately about the aim of the study and consented to donate samples for research purposes.Samples were obtained after informed consent and in accordance with procedures approved by the human ethics committee. The study included group I: 10 healthy subjects (control group) 5 male and 5 female with mean age $38.1 \pm 10.8$ yrs. And 60 $\mathrm{HCV}$ patients classified into 3 groups group II: 20 chronic HCV patients have not received treatment, 14 male and 6 female with mean age $46.7 \pm 8.6$ yrs group IIIa: 20 chronic $\mathrm{HCV}$ patients have received treatment responsive to treatment 14 male and 6 female with mean age $44 \pm 10$ years.

group IIIb: chronic HCV patients have received treatment not responsive to treatment 12 male and 8 female with mean age $43.8 \pm 6.8$ years.

The selected subjects had the following:

A. Detailed history: with special emphasis on age, sex, presence of other medical diseases.

B. Through clinical examination: laying stress on pallor, purpuric eruptions, size of liver and spleen, lymphadenopathy.

C. Routine Laboratory investigations:

1. Complete blood count (CBC) using sysmex Kx 21, with examination of Leishman stained PB smears for differential leucocytes count.

2. Liver function tests (Bilirubin total and direct, Total protein, Albumin, ALT, AST, Alkaline phosphatase. (COBAS INTEGRA 400 plus, Roche Diagnostic Ltd)
3. Kidney function tests (Blood urea and Serum creatinine) (COBAS INTEGRA 400 plus, Roche Diagnostic Ltd)

D. Special investigation:

CD81, CD19, CD22 by flowcytometry

E. Other tests:

- ANA, ASMA by ELISA (Stat Fax 303)

- RF by turbidimetry (COBAS INTEGRA 400 plus, Roche Diagnostic Ltd)

- TSH, AFP by ELFA (minividas , Biomerieux )

- HCV RNA by PCR (real time PCR, Roche Diagnostic Ltd).

*Method of CD81, CD19, CD22:

Immunophenotyping of B- lymphocytes in peripheral blood samples using BectonDickinson (BD, USA), FACS Calibur Flow Cytometry.:

\section{A-Sampling:}

$5 \mathrm{~mL}$ of venous blood were aseptically collected from each patient, divided into:

$2 \mathrm{~mL}$ blood dispensed into a tube containing K-Ethylene Diamine Tetra Acetate (KEDTA) at a concentration of $1.2 \mathrm{mg} / \mathrm{ml}$, to be used for $\mathrm{CBC}$ and preparation of Leishman stained smears PB smears and immunophenotyping of B-lymphocytes.

- $3 \mathrm{~mL}$ blood dispensed into plain tube to be used for liver and kidney function tests, ANA, ASMA, RF, AFP, TSH

\section{$B$ - Immunophenotyping of B lymphocytes:} Principle of Flowcytometry(FCM):

FCM is the measurement of numerous cell properties (cytometry) as the cells move in single file resulting in light scattering. Antibodies specific for various cellular antigens can be labeled with different fluorochromes that can absorb and emit light, allowing simultaneous multicolor flow cytometric analysis of two or more cellassociated antigens.

\section{Reagents:}

- Phosphate buffered saline (PBS) $(8.0 \mathrm{~g} / \mathrm{L} \mathrm{NaCl}$, $0.2 \mathrm{~g} / \mathrm{L} \mathrm{kcl}, 1.15 \mathrm{~g} / \mathrm{L} \mathrm{NaH} 2 \mathrm{PO} 4$ and $0.2 \mathrm{~g}$ $\mathrm{kH} 2 \mathrm{PO} 4)$ added to $100 \mathrm{~mL}$ of distilled water with $\mathrm{pH}$ adjusted at $7.3 \pm 0.2$.

- Lysing solution $(1.5 \mathrm{mmol} / \mathrm{L} \mathrm{NH4Cl}, 100$ $\mathrm{mmol} / \mathrm{L} \mathrm{KHCO3}$ and $10 \mathrm{mmol} / \mathrm{L}$ tetra $\mathrm{Na}-$ EDTA) made up to 1 liter with distilled water, $\mathrm{pH}$ adjusted at 7.2. 
- Negative isotypic control (appropriately labelled according to the MoAbs used) for determining the non-specific binding of MoAbs.

- MoAbs supplied by Beckman Coulter, France.

The panel of fluorescein isothiocyanate (FITC)/ phycoerythrin (PE) conjugated MoAbs ( CD 81,CD19,CD22)

\section{Procedure:}

\section{Surface marker analysis:}

1. Blood was prepared with PBS so that TLC was adjusted between 5 and $10 \times 10^{3} / \mathrm{mm}^{3}$.

2. For each sample, sets of tubes were labeled for all the MoAbs to be used, including 1 tube for the appropriate negative isotypic matched control MoAb.

3. $100 \mu \mathrm{L}$ of blod samples were delivered in each tube.

4. $10 \mu \mathrm{L}$ of each MoAb as well as of the isotypic negative control MoAb were added to the respective tubes.

5. The tubes were vortexed and incubated in the dark at room temperature for 15 minutes.

6. $2 \mathrm{ml}$ of PBS, as a wash buffer, were added to each tube and mixed thoroughly.

7. The tubes were centrifuged at $1500 \mathrm{rpm}$ for $5 \mathrm{~min}$ and the supernatant was discarded.

8. $1 \mathrm{~mL}$ of $1 \times 10$ lysing solution was added to each tube.

9. The tubes were vortexed and incubated for 510 minutes in the dark at room temperature.

10. The tubes were centrifuged at $3000 \mathrm{rpm}$ for 5 minutes and the supernatant was discarded.

Table (1): CBC findings in the studied groups:
11. Cells were suspended in $500 \mu \mathrm{L}$ PBS to be ready for acquiring data by the FCM.

12. $0.5 \mathrm{~mL}$ of fixative $(4 \mathrm{~g}$ paraformaldehyde in $100 \mathrm{~mL}$ PBS with $0.1 \% \mathrm{Na}$ azide, $\mathrm{pH} 7.4 \pm$ 0.2 ) was added and the tubes were kept at $4^{\circ} \mathrm{C}$ until analyzed on FCM within $24 \mathrm{hr}$.

Results: All data were analyzed using SPSS 22 for windows(IBM Corp., 2013). Continuous variables were expressed as the mean \pm SD \& median (range), and the categorical variables were expressed as a number (percentage). Independent sample Student's test was used to compare two groups of normally distributed data while Mann Whitney U test was used for non-normally distributed data. Spearman's rank correlation coefficient was calculated betweenCD81and other variables.

\section{The study showed:}

CD81, CD19, CD22 and Lymphocytic count were significantly higher in group IIIb. There was highly significant negative correlation between CD81 and total leucocytic count.There were highly significant positive correlation between liver enzymes (ALT, AST) and CD81. There was highly significant positive correlation between Total Bilirubin, Direct Bilirubin and CD81. There was also significant negative correlation between Albumin and CD81. There was highly significant positive correlation between AFP, TSH, Lymphocytes count and CD81.

\begin{tabular}{|c|c|c|c|c|c|c|}
\hline & $\mathrm{I}$ & II & IIIa & IIIb & $\mathrm{F}$ & $\mathrm{P}$ \\
\hline $\begin{array}{l}\text { TLC }(\text { count/ul }) \\
\bar{X} \pm \text { SD } \\
\text { (Range) }\end{array}$ & $\begin{array}{c}7.4 \pm 1.3^{*} \\
5.5-9.8 \\
\end{array}$ & $\begin{array}{l}4.6 \pm 1.6 \\
2.3-7.7 \\
\end{array}$ & $\begin{array}{c}4.4 \pm 1.2 \\
1.9-6.4 \\
\end{array}$ & $\begin{array}{l}4.0 \pm 1.1 \\
2.4-5.9 \\
\end{array}$ & 16.09 & $<0.001 * *$ \\
\hline $\begin{array}{l}\mathrm{HB}(\mathrm{g} / \mathrm{dl}) \\
\overline{\mathrm{X}} \pm \mathrm{SD} \\
(\mathrm{Range}) \\
\end{array}$ & $\begin{array}{r}13.2 \pm 1.3 \\
11.4-15.6 \\
\end{array}$ & $\begin{array}{l}12.3 \pm 1.3 \\
9.3-14.8 \\
\end{array}$ & $\begin{array}{c}12 \pm 1.1 \\
9.6-13.5 \\
\end{array}$ & $\begin{array}{c}12.6 \pm 1.2 \\
10.0-14.7\end{array}$ & 2.27 & 0.08 \\
\hline $\begin{array}{l}\mathrm{PLT}(\text { count/ul) } \\
\mathrm{X} \pm \mathrm{SD} \\
\text { (Range) }\end{array}$ & $\begin{array}{c}272 \pm 67 * \\
188-392\end{array}$ & $\begin{array}{c}155.8 \pm 74 \\
62-344\end{array}$ & $\begin{array}{c}135.7 \pm 39 \\
74-199\end{array}$ & $\begin{array}{c}144.2 \pm 37.3 \\
90-212\end{array}$ & 15.3 & $<0.001 * *$ \\
\hline
\end{tabular}


Table 2 : Comparison of CD81 and lymphocytic count

\begin{tabular}{|l|c|c|c|c|c|c|}
\hline & I & II & IIIa & IIIb & F & P \\
\hline CD81 & & & & & & \\
$\bar{X} \pm$ SD & $11.9 \pm 2$ & $52.3 \pm 10.9 *$ & $19.7 \pm 4.2$ & $56.8 \pm 6.9 *$ & 153.3 & $<0.001 * *$ \\
Range & $8-14$ & $34-76$ & $12-29$ & $44-70$ & & \\
\hline Lymphoctic & & & & & & \\
percentage & & & & & & \\
$\bar{X} \pm$ SD & $31.1 \pm 5.4$ & $49.4 \pm 4.8$ & $51 \pm 7$ & $52.3 \pm 10.4$ & 20.3 & $<0.001 * *$ \\
Range & $20-38$ & $39-57$ & $44-66$ & $38-78$ & 20.3 & \\
\hline
\end{tabular}

Table (3): Correlation between CD81 and other parameters.

\begin{tabular}{|l|c|c|c|}
\hline & $\mathrm{R}$ & $\mathrm{P}$ & Sig. \\
\hline ALT & 0.41 & $<0.001^{* *}$ & HS \\
\hline AST & 0.5 & $<0.001^{* *}$ & HS \\
\hline
\end{tabular}

Table (4 ): Correlation between CD81 and other parameters.

\begin{tabular}{|l|c|c|c|}
\hline & $\mathrm{R}$ & $\mathrm{P}$ & Sig. \\
\hline Bilirubin T. & 0.62 & $<0.001^{* *}$ & HS \\
\hline Bilirubin D & 0.46 & $<0.001^{* *}$ & HS \\
\hline Alb & -0.28 & $<0.05^{*}$ & Sig. \\
\hline TP & -0.11 & $>0.05$ & NS \\
\hline
\end{tabular}

Table (5): Correlation between CD81 and PCR in different groups:

\begin{tabular}{|l|c|c|c|}
\hline & $\mathrm{R}$ & $\mathrm{P}$ & Sig. \\
\hline Group II & 0.55 & $<0.001^{* *}$ & $\mathrm{HS}$ \\
\hline Group IIIa & -0.20 & $>0.05$ & $\mathrm{NS}$ \\
\hline Group IIIb & 0.41 & $<0.001^{* *}$ & HS \\
\hline
\end{tabular}

Table (6): Correlation between CD81 and other parameters.

\begin{tabular}{|l|c|c|c|}
\hline & $\mathrm{R}$ & $\mathrm{P}$ & Sig. \\
\hline Creatinine & -0.18 & $>0.05$ & NS \\
\hline AFP & 0.47 & $<0.001^{* *}$ & HS \\
\hline TSH & 0.33 & $<0.001^{* *}$ & HS \\
\hline Lymph & 0.41 & $<0.001^{* *}$ & HS \\
\hline
\end{tabular}

\section{DISCUSSION}

the present study aimed to investigate the clinical relevance and the possible mechanism of CD81 down-regulation under IFN-alpha treatment.In the present study, there were no significant differences between all groups regarding gender, age this was in accordance with (10) who founde that there was no significant difference between their patients regarding gender and age but their patients over 60 years showed higher percentage of the disease.
There were significant differences between all groups regarding TLC and PLT higher in group I this was in accordance with (11) this could be explained by bone marrow depression due to treatment with interferone, in their study they also founded that hemoglobin level was significantly reduced in their patient this was in contrary to our stud as we found no significant difference in our patients . ASMA and ANA more higher in group IIIb this was in agreement with ${ }^{(12)}$ this could be explained by the role of infectious 
agent which may induce a variety of different auto-immune diseases or different agents may play a role in the pathogenesis of a single auto-immune condition ${ }^{(12)}$.

Our study showed that ALT and AST were significantly higher in group II, this was in agreement with ${ }^{(13)(11)}$ while T. bilirubin was significantly higher in group IIIb, direct bilirubin was significnatly higher in group II due to lack of treatment. In our study, CD81, CD19, CD22 and lymphocytic count were significantly higher in group IIIb this was in accordance with ${ }^{(13)}$, and also there were a highly significant positive correlation between CD81 and PCR findings, also CD81 and ALT,AST ,total and direct bilirubin level and we noticed a significant negative correlation between albumin and CD81 level. This was due to lower levels of cell surfaceassociated CD81 are associated with $\mathrm{HCV}$ and the initial decline of HCV RNA after initiation of antiviral therapy. Peripheral Bcell CD81 expression was shown to be increased in $\mathrm{HCV}$-infected patients and was downregulated by antiviral therapy to a level comparable to that for normal controls. This effect may be directly related to antiviral therapy or indirectly to decrease of viral $\operatorname{load}^{(13)(11)}$

As suggested by ${ }^{(6)}$ the up-regulation of CD81 mRNA in this study indicates that alfa interferon-induced down-regulation of CD81 protein probably occurs at the posttranscriptional or translational level. The decrease in cell surface-associated CD81 expression induced by alfa interferon could therefore reduce the attachment of $\mathrm{HCV}$, and if $\mathrm{CD} 81$ is required for uptake of $\mathrm{HCV}$ virions, down-regulation of CD81 could also diminish de novo infection of susceptible cells. Additionally, mice lacking CD81 have enhanced $\mathrm{T}$-cell proliferation and immune responses following $\mathrm{T}$-cell antigen receptor engagement. The decreased expression of CD81 may thus enhance the immune response and facilitate virus elimination. Another possible effect of antiviral treatment on B-cell CD81 expression is an indirect effect via reducing the viral load.

Pretreatment B-cell CD81 expression is increased and that this increase is correlated with the HCV RNA level. In addition, patients with a rapid initial decline of $\mathrm{HCV}$ RNA after initiation of antiviral therapy showed a decline of cell surface-associated CD81 and had lower levels of CD81 than patients without initial virological response (14)

In this study we found that there were highly significant positive correlation between CD81 and PCR level in patients who did not receive treatment and patients who received treatment and did not respond this was in agreement with ${ }^{(14)}$, and this could be explained by the interferon-alpha-induced alteration of lymphocytic CD81. The CD81 levels in healthy subjects and naïve chronic $\mathrm{HCV}$ patients were compared, with the results showing that the two groups had comparable surface CD81 levels for total peripheral blood lymphocytes, subpopulation-B, -T, and -NK cells. In vitro interferon-alpha treatment could suppress the CD81 expression from both groups. Subsequently, they compared the in vitro interferon-alpha modulatory effects on lymphocytic CD81 from patients having received anti-HCV therapy with either sustained virological response (SVR) or without SVR. There was a significant downregulation of the B-cell's CD81 only in the SVR group. The CD81 modulation was further investigated using Daudi lymphoid cell line, showing declined surface CD81 levels following treatment with interferonalpha, interferon-beta or polyI:C. Thus, interferons could directly decrease CD81 expression. The interferon-alpha effect could be restored by 2 -aminopurine, suggesting that double-stranded RNA activated kinase might be involved in the suppression of CD81. In conclusion, CD81 down-regulation is a primary host response to interferon-alphabased therapy and an immunophenotype associated with anti-HCV SVR ${ }^{(15)}$.

\section{REFERRENCES}

1- Kim CWand Chang KM.(2013):Hepatitis C Virus: virology and life cycle. Clin Mol Hepatol. 19(1):17-25.

2- Elgharably A,Goma AI ,Crossey MM,Northworthy PJ ,Waked I,Robinson SDT(2017):Hepatitis C in Egypt -past,present and future.Int J Med;10-1-6

3- Zhao, Zhong L, Elizabeth Elrod, Evi Struble, Li Ma, Hailing Yan, Christine Harman, Lu Deng, Maria Luisa Virata- 
Theimer, Peter Liu, Harvey Alter, Arash Grakoui, and Pei Zhang(2014): A Neutralization Epitope in the Hepatitis C Virus E2 Glycoprotein Interacts with Host Entry Factor CD81 .PLoS One. 2014; 9(1): e84346.

4- Raphael I , Nalawade S, Eagar T N, and Forsthuber T G (2015):T cell subsets and their signature cytokines in autoimmune and inflammatory diseases. Cytokine; 74(1): 5-17.

5-Dustin LB(2017):Innate and adaptive immune responses in chronic HCV infection .Curr Drug Targets;18(7):826-843.

6- Fénéant L, Levy S, and Cocquere L(2014): CD81 and Hepatitis C Virus (HCV) InfectionViruses. 6(2): 535-572.

7-Cowton VM, Angus AGN, Cole SJ, Markopoulou CK Owsianka A, Dunlop JI, Gardner DE, Patel AH (2016): Role of Conserved E2 Residue W420 in Receptor Binding and Hepatitis C Virus Infection. J. Virol. vol. 90 no. 16 7456-7468

8-Cook N,Truse EP, Garcia AS,Hardigan P, Amofah SA (2016):Hepatitis C virus infection screening within community health centers.Journal of Osteopathic Association:116-(1)6-11.

9-Daw MA ,El-Bozedi A,Ahmed MO,Dau AA,Agnan MM(2016):Hepatitis C virus in north Africa :An emerging threat .Scientific World Journal:7370524.
10- 12-Niu ZL, Zhang PA, and Tong Y Q(2016): Age and gender distribution of Hepatitis $C$ virus prevalence and genotypes of individuals of physical examination in WuHan, Central ChinaSpringerplus. 5(1): 1557.

11-Rehman A U, Ali F, Ali M , Alam I, Khan A $\mathrm{W}(2016)$ :Changes in hematological parameters with pegylated interferone in chronic hepatitis $\mathrm{C}$ virus infected patients.Asian Pac J Cancer Prev.17(5),2485-2490

12- Acay , Demir K, Asik G, Tunay $\mathrm{H}$, and Acarturk(2015): Assessment of the Frequency of Autoantibodies in Chronic Viral Hepatitis Pak J Med Sci. 31(1): 150-154.

13-Alam I, Alam I and Ali I (2014):Weight loss in HCV patients can be used as a surrogate marker for evaluation of interferone (INF- $\alpha$ ) treatment efficacy a prospective pilot study .Pak J Pharm Sci,27,57:1-6

14- Martin, D.N, Uprichard, S.L.(2013):Identification of transferrin receptor 1 as a hepatitis $\mathrm{C}$ virus entry factor. Proc. Natl. Acad. Sci. USA, 110, 1077710782.

15-Chang LL, Cheng PN, Chen JS and Young KC (2007): CD81 down-regulation on B cells is associated with the response to interferonalpha-based treatment for chronic hepatitis $\mathrm{C}$ virus infection. Antiviral Res; 75(1): 43-51. 